How to Cite:

Onyshchenko, K. M., Hiha, S. P., Hlukhanych, O. M., Zelinka, V. S., \& Vihula, V. I. (2021). Interaction of national cultures in the development of musical life of Transcarpathia in the second half of the 20th century. Linguistics and Culture Review, 5(S2), 722-732.

https://doi.org/10.37028/lingcure.v5nS2.1415

\title{
Interaction of National Cultures in the Development of Musical Life of Transcarpathia in the Second Half of the 20th Century
}

\author{
Kateryna M. Onyshchenko
}

Uzhhorod Institute of Culture and Arts, Uzhhorod, Ukraine

Stepan P. Hiha

Uzhhorod Institute of Culture and Arts, Uzhhorod, Ukraine

Olesia M. Hlukhanych

Uzhhorod Institute of Culture and Arts, Uzhhorod, Ukraine

Valentyna S. Zelinka

Uzhhorod Institute of Culture and Arts, Uzhhorod, Ukraine

Valentyna I. Vihula

Uzhhorod Institute of Culture and Arts, Uzhhorod, Ukraine

\begin{abstract}
The development of musical life and culture of Transcarpathia had been influenced by different cultures. Recently, scholars have paid attention to the problem of historical development of the region, as well as the study of the cultural heritage of Transcarpathia. These studies are crucial within the framework of studying various aspects of regional history, which strive to avoid stereotypes, subjectivism, and other factors. The purpose of this study is to identify different cultural influences on Transcarpathian musical life in the second half of the 20th century. The research methodology is based on such theoretical methods as synthesis and analysis of information, as well as the historical method. Cultural studies and socio-cultural approaches were used. In addition, the theoretical analysis of academic literature was conducted in this study. The multiculturalism of Transcarpathia in the middle and at the end of the 20th century was considered in this study. It was determined that in the second half of the 20th century the leading ethnic groups in the region, who were Ukrainians, Hungarians and Romanians, coexisted within different small territories and zones. Small groups of Russians, Germans, Slovaks, Jews and Roma have also lived among them. The Transcarpathian musical life was studied through the works of
\end{abstract}

Linguistics and Culture Review @ 2021.

Corresponding author: Onyshchenko, K. M.; Email: km-onyshchenko6478-1@uohk.com.cn

Manuscript submitted: 9 April 202 1, Manuscript revised: 18 June 2021, Accepted for publication: 28 July 2021

722 
Desiderius Zador and Stepan Marton in particular. The Soviet period of Transcarpathian history was considered. The information presented in this study can be used during lectures or seminars about the history of musical culture, as well as for individual study of the history of Transcarpathian musical life.

Keywords---cultural and artistic life, musical traditions, musicology, transcarpathian composers, transcarpathian music, Ukrainian culture.

\section{Introduction}

Transcarpathia is a historical region located at the intersection of north, east and west of Europe. Therefore, its geopolitical location is considered to be unique, since the Transcarpathian region is located at the intersection of not only economic and trade routes but also of national and cultural ones (Csernicskó \& Fedinec, 2020). This geopolitical location has contributed to multilateral interethnic and interstate cooperation. Recently, scholars have paid attention to the problem of historical development of the region (Aleksandrova, 2017). These studies are crucial within the framework of studying various aspects of regional history, which strive to avoid stereotypes, subjectivism, and other factors. A development of Transcarpathian musical culture at the beginning of the 20th century had certain specificities. Not belonging to a new state for centuries, economic backwardness of the region and frequent changes of political regime were some objective reasons for the slower cultural and artistic process of the region than in neighbouring Ukraine, Hungary and Czechoslovakia (Kuzyshyn, 2019). The region's accession to the Czechoslovak Republic contributed to emergence of new trends in Transcarpathian musical culture. At that time, this territory of the Carpathians acquired the name of Subcarpathian Rus. During this historical period, three was an active process of developing musical and culturaleducational societies, creating a large number of choirs and instrumental ensembles (Fedinec \& Csernicskó, 2017). Prosvita was one of the first organisations to consistently defend the Ukrainian idea of Subcarpathian Rus during the interwar period. An activist of the Ukrainian national movement Yu. Braschaiko was a leader of the Prosvita organisation throughout its existence.

The cultural policy of the Transcarpathian region was embodied by professionalising all areas. In the period from 1945 to 1946, six children's music schools were established in such Transcarpathian cities as Uzhhorod, Mukachevo, Berehiv, Vynohradiv, Khust, and Solotvyno. A musical college was also established in Uzhhorod. Despite achieving certain success, music schools experienced a shortage of staff, which was resolved primarily by reducing the training period for teachers. The accelerated method of providing music education included only verifying the professional level of the musician and giving a diploma that would approve of their knowledge. Some 20th-century musicians and composers including Marton, chose such education. Soviet academic sources ignore the existence of a music school "Philharmonic" during the interwar period, as well as a network of private music schools. Particularly, there were schools of J. Lendel, N. Ploteni, S. Dnistryanska and E. Gorachek. Systematic choral 
courses and thorough music training allowed graduates to perform musicalpedagogical and theatrical activities successfully or even create musical pieces (Malynovska, 2016).

The purpose of this study is to determine the influence of different cultures on Transcarpathian musical life. In addition, the primary purpose of this study is to determine the specificities and main characteristics of Transcarpathia $\mathrm{n}$ musical life in the second half of the 20th century (Konovalova, 2021; Mileto et al., 2017).

\section{Materials and Methods}

The methodology of this study is based on theoretical methods such as synthesis and analysis of information, the historical method. Cultural studies and sociocultural approaches were used. In addition, the theoretical analysis of academic literature was conducted in this study. Methods of synthesis and analysis were used to study the interaction of national cultures in the development of Transcarpathian musical life during the second half of the 20th century. Methods of analysis and synthesis of information are interdependent methods of cognition. The analysis supposes disintegrating the subject matter for the comprehensive study of its main parts. The analytical method is focused on determining the internal tendencies and capabilities of the subject (Dei \& Salvadori, 2006; Katsanos et al., 1999). It is common for all disciplines. Synthesis is a reverse process that combines previously selected symbols, properties, and relationships into one. However, this is not a simple mechanical combination of previously distinguished elements but a process of cognition, where the place and the role of each element in the system is revealed. The historical method was also used for this study. The historical method is based on the study of the origin, emergence and development of objects in chronological order. Thus, it was used to analyse the interaction of national cultures in the development of Transcarpathian musical life during the second half of the 20th century.

The methodology of this study included a cultural studies approach which integrates the research potential accumulated by many sciences that study culture. In particular, the research potential is integrated with sciences such as philosophy of culture, theory of culture, history of art, cultural studies psychology, sociology of culture, history of culture (Bird \& Stevens, 2003; Krumbholz \& Maiden, 2001). This approach is used with the intention to analyse the subject as a cultural phenomenon. Within the cultural studies approach, culture is considered to be a system that develops and functions in interaction with objective and subjective forms. The cultural studies approach was used for better understanding of different cultural influences on the development of Transcarpathian musical art. For the same purpose, this study used a sociocultural approach, which focuses primarily on strategic social goals of historical reproduction of society and its national cultural specifics and systemic characteristics of complexes of cultural value, social adequacy and cultural competence of new members of society. This method provides a multifactorial approach to the study of socio-cultural environments and means of communication of social and cultural systems (Penhune, 2011; Jentschke \& Koelsch, 2009). 
The theoretical analysis of the academic literature related to the subject matter was conducted in the study. Scholarly articles of Ukrainian and foreign authors were considered and analysed. In the first article, the authors discuss the musical exchange between Moroccans and Spaniards, which is often supported by the concept of a common cultural heritage. Thus, this article implies a dialogue between ethnomusicology and science about the politics and everyday realities of multiculturalism and intercultural activity (MacHin-Autenrieth, 2020). In the next article, the authors note that from the beginning of the 20th century to the present day Transcarpathia belonged to several states which were the AustroHungarian monarchy, Czechoslovakia, the Kingdom of Hungary, the Soviet Union and, finally, Ukraine. Based on the long-term research and one-month fieldwork conducted by Laikhonen in 2012, the authors strive to provide an independent critical presentation and analysis of the discourse of the Transcarpathian situation in the 20th century (Csernicskó \& Fedinec, 2020). In the last considered work the author reveals the importance of Ukrainian music culture in the process of emergence and development of music education in the country during the first half of the 20th century. The author explores the significance of fraternal schools for the development of music education. The author emphasises the importance of Lysenko's musical career and public work for the development of modern music education (Bielikova, 2019).

\section{Results}

\section{Multiculturalism in Transcarpathia}

Since the ancient times, the borders of modern Transcarpathia differed in their social and national diversity. In the second half of the 20th century, the region's leading ethnic groups, who were Ukrainians, Hungarians and Romanians, coexisted in various small territories and zones. The small groups of Russians, Germans, Slovaks, Jews and Roma also lived among them. Excluding Russians, they have been scattered in the ethnic composition of the region at certain historical intervals since the late 18th century. Hutsuls, Boyky, Lemky and Dolyniany represented the composition of the dominant Ukrainian ethnos. During the Soviet period, the population of Transcarpathia grew by 65\% (Csernicskó \& Beregszászi, 2019). After the demographic crisis during the Second World War, the region experienced peaceful and favourable times for improvement of the demographic situation. Thus, it became one of the exemplary regions, known for a high birth rate. The highest population growth in Transcarpathia was dated between 1950 and 1960. There was a population explosion around the world. At that time, one family raised up to five children on average (Amrakhova, 2017).

In the late 1980s, the family had two or three children. Population growth has slowed down but Transcarpathia has managed to achieve positive rates, despite growing depopulation in many regions of Ukraine. In 1946, 776.000 people lived in the Transcarpathian region, and in the late sixties their number exceeded one million. In 1990, 1 million 254 thousand inhabitants were registered in Transcarpathia. This was almost two and a half percent of Ukrainian population. Starting from the 1960s and ending with the 1990s, the population of Ukraine has increased by 23\%, while in the Transcarpathian region the population has increased by more than $36 \%$. Thus, Transcarpathia had the highest population 
growth rate among all oblasts (Csernicskó \& Fedinec, 2020). Finally, Transcarpathia was recognised as a densely populated area of Europe. The population density there was 98 people per square kilometre. However, the lack of jobs led to the situation where about one in five Transcarpathian was a seasonal labour migrant. Given this, the population of the leading cities, which were Uzhhorod and Mukachevo, has doubled. For example, 48.000 people lived in the regional centre Uzhhorod in 1959, and three decades later the city's population was more than 117.000 .

Changes in social and national composition occurred primarily due to natural movement and migration (Gao, 2020). At the same time, different ethnic groups of Transcarpathia had different ways of natural reproduction, which are associated with traditions, living in a village or city, in the mountains or on the plains. In the 1960's and 1980's the Transcarpathian national consciousness could be described as an unstable worldview. The persecuted historical and cultural traditions were combined in unexpected ways with the new socialist forces imposed by the state party apparatus. However, traditional morals and ethnic stereotypes were still determined by family and calendar rituals. On the personal level, the national consciousness of the population was based on traditions. Their destruction was caused primarily by changes in the social, political and cultural status of the family. Urbanisation and Russification have significantly weakened the passing down of information from generation to generation (Morshchakova, 2016).

Within the circles of the Transcarpathian intelligentsia, the development of national culture was an alternative to the communist ideology. New personalities obsessed with the ideas of national liberation have emerged due to the disappointment with the socio-political policy of the USSR (Opanasiuk, 2018).

\section{Analysis of the musical life of Transcarpathia}

The emergence of amateur art groups was the crucial factor for the development of concert life in Soviet Transcarpathia. Music studios and associations, choral and instrumental ensembles, theatrical groups of companies and organisations managed by urban and rural houses of culture and inspired by the ideas of collectivism became extremely popular. At the same time, the data from the district people's educational councils, which formed the official statistics of the Subcarpathian People's Educational Union, shows that in 1936 there were 170 choirs, 54 orchestras and more than 300 amateur theatre groups. These facts also refute the idea of complete renewal of all areas of Transcarpathian musical life during the Soviet period (Varnava, 2017).

Notable, there was a clear tendency towards centralisation and control over the entire regional music infrastructure activities within the USSR. The cultural policy of the Soviet Union led to the professionalisation of amateur movements by inviting professional musicians to organise amateur groups. At the same time, the practice of systematic reviews, competitions, decades, festivals and skills competitions in amateur art was introduced, which would be impossible without organised forms of performance, training and without the effective assistance of professional musicians. Thus, professionals were given the opportunity to show 
themselves in various roles such as a musician-performer, a composer who enriches the repertoire of the group, and a creative mentor (Konovalova, 2014; Karas et al., 2019).

Desiderius Zador (1917-1985) and Stepan Marton (1923-1996) reassured the glory of Transcarpathia as a musical region. Zador's highest achievements were symphonic pieces, while Marton's passion was the organ. In 1934 D. Zador graduated from the Prague Conservatory. He was recognised as a pianist, composer, folklorist and musicologist (Vereshchahina-Biliavska et al., 2021; Pople, 1992). He is the author of the symphonic poem "Verkhovyna", a cantata for mixed choir "Karpaty" based on the lyrics of Yu. Goyda. Moreover, he is considered as the founder of professional music education in the Transcarpathian region. Zador was the first director of the Uzhhorod State Music School founded in 1946. S. Marton stands out with variations on the theme of the song "Rain Will Fall" for violin unison, as well as musical compositions for the films "Over the Tisza" and "In the Carpathians". The world-famous composer Yevhen Stankovych was one of the most talented students of Stepan Marton, who taught at the Uzhhorod Music School at the time. Almost all musical genres are represented in E. Stankovych's works. Stankovych wrote 15 symphonies, 5 ballets, folk opera, 4 instrumental concerts, Kaddish requiem, chamber-instrumental and large choral vocal-symphonic pieces. He wrote music for lyrics from the Bible, texts by $\mathrm{T}$. Shevchenko, O. Pushkin, P. Tychyna, D. Pavlychko, P. Movchan. He has also composed music for more than a hundred films and theatrical performances. Yevhen Stankovych was primarily a symphony composer (Volkov, 2015). He gained worldwide recognition for this work. Symphony No. 3 "I argue" based on the lyrics of P. Tychyna for the reader, choir and symphony orchestra was written in 1976 and won the Shevchenko Prize. His 1985 chamber symphony No. 3 for flute and 12 strings was recognised by the UNESCO Commission as one of the ten best symphonies in the world.

In the 20th century D. Zador made a significant contribution to the emergence and development of professional music education in Transcarpathia. He was the first one to gradually build a system of professional music education. He also played a crucial role in establishment of the Uzhhorod State Music School. notably, Zador was engaged in both compositional and pedagogical activities during his life. Starting from the 1950s, Zador has worked as the art director of the Transcarpathian Regional Philharmonic. In the 1950s, the composer wrote a large number of musical works. He composed such adaptations of folk songs as "The Rain Will Fall", "Oh, the Violets Bloomed", "The Fortune Teller", "The Ballad of Dovbush", and a number of romances as well. D. Zador's friendship with the poet Yu. Goyda inspired the composer to write a vocal-symphonic piece the cantata "Carpathians". This piece of music is one of the significant achievements of Ukrainian musical art. The diversity of Zador's work has given him a large number of fans and considerable popularity (Konovalova, 2018).

The composer combined his active creative and pedagogical work with public activism. He promoted Transcarpathian art and folk songs in particular (Otera et al., 2013; Bensimon \& Gilboa, 2010). For a long time, D. Zador was the chairman of the association of amateur composers of Transcarpathia, which he founded in 1959 in the House of Folk Art. At the end of his life, D. Zador was associated with 
the conservatory in Lviv. He was engaged in composing and performing activities. He realised his creative potential as an associate professor first and as a professor of composition later (Kulbizhekov, 2013). D. Zador's performances in the concert halls of Uzhhorod, Drohobych, Lviv and Kyiv alternated with intensive work on new musical pieces. In 1963 D. Zador wrote a piano concerto with orchestra and symphonic poems "Verkhovyna", "Carpathian rainbow". At the same time, a record of the cantata "Karpaty" was released. It was performed by the Lviv choir "Trembita" and a symphony orchestra.

\section{Discussion}

Researchers of culture and music of Transcarpathia are viewing the development and emergence of regional culture through the prism of multiculturalism. Many nationalities have always lived in Transcarpathia. All of them influenced the development of the culture of the region in general. Some scholars have discussed multiculturalism and its impact on society and culture. Here are some scholarly articles related to the subject matter. In the first article, the authors discuss the musical exchange between Moroccans and Spaniards, which is often supported by the concept of a common cultural heritage. These exchanges promote intercultural dialogue and the social integration of Moroccans in Andalusia. Focusing on one individual, the authors explore the musicians' strategies for social and musical integration into Andalusian society. They explore the ways in which Moroccan musicians agree on their everyday musical landscape and the tensions between vivid cultural differences, social integration, and their personal artistic aspirations. Thus, this article suggests a dialogue between ethnomusicology and science about the politics and everyday realities of multiculturalism and intercultural activity (MacHin-Autenrieth, 2020).

In the next article, the authors note that from the beginning of the 20th century to the present day Transcarpathia belonged to several states which were the Austro-Hungarian monarchy, Czechoslovakia, the Kingdom of Hungary, the Soviet Union and, finally, Ukraine. The status of the language, which is considered to be the language of minorities and majorities, changed with the ruling nationality. Based on the long-term research and one-month fieldwork conducted by Laikhonen in 2012, the authors strive to provide an independent critical presentation and analysis of the discourse of the situation in Transcarpathia. The authors present examples, particularly from the linguistic landscape, where it is noted that hybrid practices are difficult to capture by other means. Different nation-states tend to evaluate certain languages in comparison with others. However, Transcarpathia was too far away from different national centres, and, therefore, it remained a periphery. In everyday life of Transcarpathia, the issue of the language, standardisation and heteroglossia comes into the picture in modern times especially. Such unexpected linguistic practices, or "before-nationalist" and "non-purist" ideologies suggest changes to see how certain categories, such as language, have remained in their hybrid forms and are still clearly in the making (Csernicskó \& Laihonen, 2016).

In the last article, the author reveals the importance of Ukrainian music culture in the process of emergence and development of music education in the country during the first half of the 20th century. The value of this study lies in the 
development of scientific thought spread to the disciplines related to culture: cultural anthropology, sociology of culture and philosophy of culture. The culture of a person working in the field of education is integrative by nature and is revealed in one's behaviour. The author explores the importance of fraternal schools for the development of music education. The scholar emphasises the significance of musical creativity and public activity of N.V. Lysenko for the development of modern music education (Bielikova, 2019). Currently, there are insufficient academic studies on intercultural influence on the development of their culture in a particular region. In particular, the topic of Transcarpathia, its cultural and social life is also insufficiently studied. The number of sources about Transcarpathian culture in the 20th century is very limited. Thus, it should be noted that this topic requires further study and new development.

\section{Conclusion}

Transcarpathia is a historical region located at the intersection of northern, eastern and western Europe, so its geopolitical location is considered to be unique, since the Transcarpathian region is located at the intersection of not only economic and trade routes but also national and cultural ones. A special development of Transcarpathia musical culture happened in the early 20th century. The cultural and artistic process in the region was a bit slower than in neighbouring Ukraine, Hungary and Czechoslovakia. New trends in Transcarpathia musical culture became widespread during the accession of the region to the Czechoslovak Republic. The cultural policy of the Transcarpathian region was performed by professionalising all areas. In the period from 1945 to 1946, six children's music schools were opened in Transcarpathia. A musical college was also opened in Uzhhorod.

Since the ancient times, the borders of modern Transcarpathia differed in their social and national diversity. In the second half of the 20th century, the dominant ethnic groups of the region who were Ukrainians, Hungarians and Romanians, coexisted in various small territories and zones. small groups of Russians, Germans, Slovaks, Jews and Roma also lived among them. The emergence of amateur art groups was the crucial factor for the development of concert life in Soviet Transcarpathia. Music studios and associations, choral and instrumental ensembles, theatrical groups of companies and organisations managed by urban and rural houses of culture and inspired by the ideas of collectivism became extremely popular. Desiderius Zador (1917-1985) and Stepan Marton (19231996) have reassured the glory of Transcarpathia as a musical region. In the 20th century D. Zador contributed significantly to the emergence and development of professional music education in Transcarpathia. He was the first one to gradually build a system of professional music education. He also played an important role in establishment of the Uzhhorod State Music School. Notably, Zador was engaged in both compositional and pedagogical activities during his life. Thus, the main figures in the musical life of Transcarpathia in the 20th century were Marton, Zador, and Marton's student composer Stankovych, who gained worldwide recognition and popularity.

Currently, the academic community presents insufficient studies on intercultural influence on the development of culture in a particular region. In particular, the 
topic of Transcarpathia, its cultural and social life is also understudied. There are almost no studies researching the culture of Transcarpathia in the 20th century. Thus, this subject area requires further investigation and research.

\section{References}

Alexandrova, OO (2017). Vocal and choral style of G. Svyridov: interaction of local and religious aspects.

Amrakhova, A. (2017). Modern musical culture. In search of self-determination. Moscow: "Composer".

Bensimon, M., \& Gilboa, A. (2010). The music of my life: The impact of the musical presentation on the sense of purpose in life and on selfconsciousness. The arts in Psychotherapy, 37(3), 172-178. https:/ / doi.org/10.1016/j.aip.2010.03.002

Bielikova, V.V. (2019). Ukrainian musical culture in the context of modern multicultural space. Sciences of Europe, 37-3(37), 15-19.

Bird, A., \& Stevens, M. J. (2003). Toward an emergent global culture and the effects of globalization on obsolescing national cultures. Journal of International Management, 9(4), 395-407. https://doi.org/10.1016/j.intman.2003.08.003

Csernicskó, I., \& Beregszászi, A. (2019). Different states, same practices: visual construction of language policy on banknotes in the territory of present-day Transcarpathia. Language policy, 18(2), 269-293.

Csernicskó, I., \& Fedinec, C. (2019). Time and Space in Between: Time Zones, Languages and Cultures in Transcarpathia (Ukraine). Acta Universitatis Sapientiae Philologica, 11(2), 7-22.

Csernicskó, I., \& Laihonen, P. (2016). Hybrid practices meet nation-state language policies: Transcarpathia in the twentieth century and today. Multilingua, 35(1), 1-30.

Dei, L., \& Salvadori, B. (2006). Nanotechnology in cultural heritage conservation: nanometric slaked lime saves architectonic and artistic surfaces from decay. Journal of cultural Heritage, $7(2), \quad 110-115$. https://doi.org/10.1016/j.culher.2006.02.001

Fedinec, C., \& Csernicskó, I. (2017). What time is it, Mr. Vekker ?: Time zones and politics in Transcarpathia. COMMENTARY, (2), 81-99.

Gao, W. (2020, October). Research on the Coordinated Development and Innovative Application between National Music and Contemporary Multicultural Music Education Based on Big Data. In Journal of Physics: Conference Series (Vol. 1648, No. 3, p. 032063). IOP Publishing.

Jentschke, S., \& Koelsch, S. (2009). Musical training modulates the development of syntax processing in children. Neuroimage, 47(2), 735-744. https://doi.org/10.1016/j.neuroimage.2009.04.090

Karas, H. V., Serhaniuk, L. I., Kazymyriv, K. T., Bardashevska, Y. M.\& Maskovych, T. M. (2020). Diaspora art project as a factor to protect Ukrainian music culture in the modern transformational processes. Asia Life Sciences, Supp, 22(2), 201-214.

Katsanos, N. A., De Santis, F., Cordoba, A., Roubani-Kalantzopoulou, F., \& Pasella, D. (1999). Corrosive effects from the deposition of gaseous pollutants on surfaces of cultural and artistic value inside museums. Journal of hazardous materials, 64(1), 21-36. https://doi.org/10.1016/S03043894(98)00241-6 
Konovalova, I. (2014). The aura of the composer's personality and creativity in the artifacts of his epistolary heritage. Traditions and innovations in higher architectural and artistic education , (1), 30-34.

Konovalova, I. (2018). The Composer Phenomenon in the 20th century European Music Cultural Space: Modes of Theoretical Understanding. Kharkiv: TOV "Planeta-Print"[in Ukrainian].

Konovalova, I. Y. (2021). The composer phenomenon in a historical retrospect of an authorship idea formation in European musical culture of the middle ages. Linguistics and Culture Review, 5(S2), 284-302.

Krumbholz, M., \& Maiden, N. (2001). The implementation of enterprise resource planning packages in different organisational and national cultures. Information systems, 26(3), 185-204. https:/ / doi.org/10.1016/S0306-4379(01)00016-3

Kulbizhekov, V. (2013). Rational Foundations of Musical Creativity: Mechanisms of Thought Experiment in Classical Western European Music of the New Age. Moscow: LIBROKOM.

KUZYSHYN, A. (2019). Spatial diversification of the social sphere development in the Carpathian-Podillia region. Folia Geographica, 61(2), 144-162.

Machin-Autenrieth, M. (2020). The Dynamics of Intercultural Music Making in Granada: Everyday Multiculturalism and Moroccan Integration. Ethnomusicology, 64(3), 422-446.

Malinovska, N. (2016). Creative process of a composer in their gender manifestations: psychobiological context. Ukrainian Musicology: A Collection of Scientific Papers, 41, 91-110.

Mileto, S., Kaiser, E., Rassamakin, Y., \& Evershed, R. P. (2017). New insights into the subsistence economy of the Eneolithic Dereivka culture of the Ukrainian North-Pontic region through lipid residues analysis of pottery vessels. Journal of Archaeological Science: Reports, 13, 67-74. https://doi.org/10.1016/j.jasrep.2017.03.028

Morshchakova, N. (2016). Musical Creativity and the Subjective World of the Artist: the Context of Culture Creation. Path of Science, 2(10), 2-17.

Opanasiuk, O. P. (2018). Intentionality in the culture: art studies, culturological and philosophical aspects]: monograph. Kyiv: Aura Buks [in Ukrainian].

Otera, M., Horike, H., \& Saito, T. (2013). Musical life review for the elderly with dementia as spiritual care-Clinical functions and roles of meaningful or memorable songs. The Arts in Psychotherapy, 40(3), 285-290. https://doi.org/10.1016/j.aip.2013.05.012

Penhune, V. B. (2011). Sensitive periods in human development: evidence from musical training. cortex, 47(9), https://doi.org/10.1016/j.cortex.2011.05.010

Pople, A. (1992). Computer music and computer-based musicology. Computers \& Education, 19(1-2), 173-182. https://doi.org/10.1016/0360-1315(92)90023-X

Varnava, R. A. (2017). Psykholohichnyi portret kompozytora yak dzherelo piznannia" obrazu avtora"(na prykladi Borysa Liatoshynskoho ta Vasylia Barvinskoho).[Psychological Portrait of the Composer as a Source of Knowledge of the" image of the author"(on the Example of Borys Lyatoshynsky and Vasyl Barvinsky)](PhD Dissertation). Mykola Lysenko Lviv National Music Academy, Lviv [in Ukrainian]. 
Vereshchahina-Biliavska, O. Y., Cherkashyna, O. V., Moskvichova, Y. O., Yakymchuk, O. M., \& Lys, O. V. (2021). Anthropological view on the history of musical art. Linguistics and Culture Review, 5(S2), 108-120.

Volkov, S. (2015). Personality and time: culturological dimension. Journal of the P.I. Tchaikovsky National Music Academy of Ukraine, 3, 123-126. 